\title{
Ni-catalyzed direct carboxylation of unactivated alkyl electrophiles with carbon dioxide
}

\author{
Wenzhen Zhang*, Chunxiao Guo, Xiaobing Lü
}

Carbon dioxide is a cheap, abundant and renewable C1 building block. Over the last two decades, considerable research efforts have been devoted to developing new reactions for the efficient incorporation of carbon dioxide into a broad range of compounds for the production of value-added materials [1]. Notably, these efforts have culminated in the development of several transition-metal-catalyzed methods capable of providing access to numerous synthetically important carboxylic acids and derivatives using carbon dioxide as a carboxylative reagent [2]. In most of these cases, carbon dioxide acts as an electrophile or cycloaddition partner, which can react with a broad range of nucleophiles and unsaturated compounds [3]. In addition to these traditional cross-coupling reactions, there have been several recent reports describing the development of a transition-metal-catalyzed reaction for the reductive cross-coupling of two different electrophiles. This new reaction represents a more straightforward approach for the construction of carbon-carbon bonds, because it avoids the many tedious and expensive pre-activation steps required by the traditional processes described above for the preparation of airand/or moisture-sensitive organometallic reagents [4-6]. For this reason, the direct reductive carboxylation of (pseudo)halide electrophiles with carbon dioxide represents a more attractive and environmentally friendly method for the synthesis of functional carboxylic acids [7].

In 2009, Martin and co-workers [8] reported the first catalytic reductive carboxylation of an electrophile with carbon dioxide, where an aryl bromide was successfully carboxylated under $1 \mathrm{MPa}$ of carbon dioxide pressure using a palladium/ $t \mathrm{Bu}-\mathrm{XPhos}$ catalyst and two equivalent of $\mathrm{ZnEt}_{2}$ as a reducing agent. Tsuji and co-workers [9] subsequently reported the development of an elegant nickel-based catalytic system for the direct carboxylation of aryl and vinyl chlorides under atmospheric carbon dioxide at room temperature using $\mathrm{Mn} / \mathrm{Et}_{4} \mathrm{NI}$ as a reducing agent, which was easy to handle. Notably, mechanistic studies revealed that a $\mathrm{Ni}(\mathrm{I})$ species was formed as a key intermediate during this catalytic carboxylation cycle [9]. Further studies by Martin's group demonstrated that this nickel-catalyzed reductive carboxylation could be applied to a vari- ety of different electrophiles, including benzyl halides [10], aryl and benzyl esters [11], and allyl esters [12] using carbon dioxide. However, the direct carboxylation of unactivated alkyl electrophiles bearing a $\beta$-hydrogen remains a challenging area of research, because substrates of this type are reluctant to undergo the oxidative addition step required to initiate the reaction. Moreover, the alkylmetal intermediates formed in situ from these substrates are prone to competitive side reaction, including $\beta$-hydride elimination and homodimerization reactions.

Martin's group [13] recently reported an important breakthrough in this area when they achieved the direct carboxylation of a series of unactivated primary alkyl bromides and sulfonates bearing $\beta$-hydrogens with carbon dioxide (Scheme 1). Notably, this reaction required the presence of a nickel catalyst, as well as a 1,10-phenanthroline-type ligand. Furthermore, a series of screening experiments revealed that the optimal catalytic system for this reaction was $\mathrm{NiCl}_{2}$-glyme/2,9-diethyl-1,10phenanthroline (L1, Scheme 1), which not only allowed for the direct carboxylation of these challenging substrates, but also suppressed the unwanted side reactions. It is noteworthy that the other nickel/phosphine catalyst systems previously reported for the carboxylation of other electrophiles were found to be inefficient in this case. Furthermore, the electronic and steric properties of the 1,10-phenanthroline ligand were found to have a profound effect on the product selectivity of this

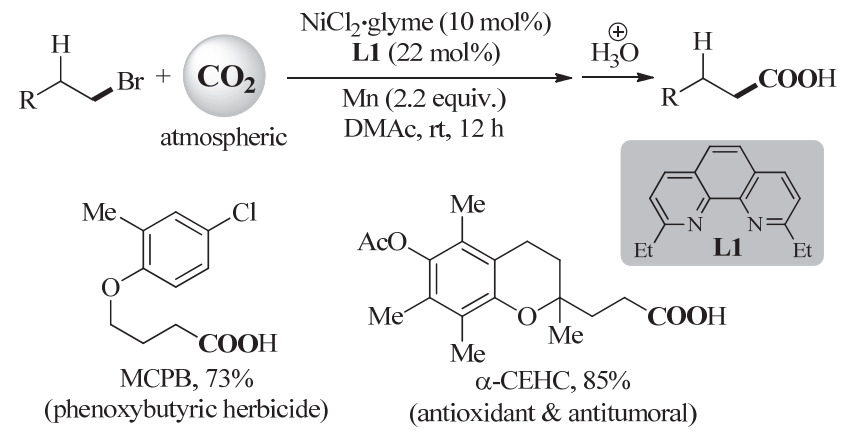

Scheme 1. Ni-catalyzed direct carboxylation of unactivated alkyl bromide with carbon dioxide. 


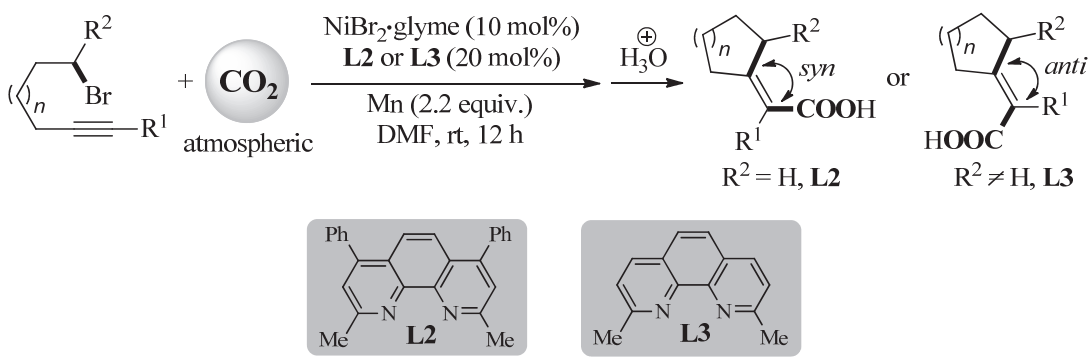

Scheme 2. Ni-catalyzed cascade reductive cyclization/carboxylation of unactivated alkyl bromides with carbon dioxide.

transformation. For example, subtle changes in the structure of the ligand backbone led to a pronounced decrease in the yield or the complete failure of the reaction.

This nickel catalyst system allowed for the direct carboxylation of a wide variety of unactivated primary alkyl bromides bearing $\beta$-hydrogen to give the corresponding carboxylic acids in good yields using $\mathrm{Mn}$ as reducing agent under an atmosphere of carbon dioxide at room temperature. Notably, this catalyst system exhibited good functional group compatibility, with ester, nitrile, acetal, amide, carbamate, ketone, aldehyde, alcohol, phenol, and aryltin groups being well tolerated. Furthermore, substrates containing an aryl chloride, tosylate, or pivalate group, which had been previously evaluated under similar Ni-catalyzed conditions, reacted exclusively at the bromide sites. Although unactivated primary alkyl chlorides and iodides, secondary alkyl bromides, and phenethyl electrophiles proved to be unsuitable substrates for the present catalytic system, unactivated alkyl sulfonates reacted smoothly using a $\mathrm{NiBr}_{2}$-glyme/2,9-dimethyl-1,10-phenanthroline catalyst at elevated temperatures. Based on its high catalytic efficiency and operational simplicity, this protocol represents an extremely useful process for practical organic synthesis. This process was also successfully applied to the concise synthesis of two biologically active compounds, namely MCPB and $\alpha$-CEHC, to highlight its synthetic utility (Scheme 1).

Mechanistic studies ruled out the possibility of the alkene generated by the $\beta$-hydride elimination of the substrate undergoing a hydrocarboxylation reaction or the involvement of an organomanganese species. Based on the results of a cleverly-designed diastereoisomer experiment and several radical clock reactions, the authors suggested that the catalytic cycle involved several SET processes and proceeded via a $\mathrm{Ni}(\mathrm{I})$ species.

Based on the nickel/nitrogen ligand catalytic system described above, Martin's group [14] recently reported the cascade reductive cyclization/carboxylation of unactivated alkyl bromides bearing an internal alkyne group under an atmosphere of carbon dioxide. Notably, this reaction provided facile access to a series of carbocyclic carboxylic acids in good yields (Scheme 2). Remarkably, the syn/anti selectivity of this reaction could be readily modulated by the substrate selection and/or ligand backbone.

In summary, Martin and co-workers have successfully developed an efficient catalytic system for the nickel-catalyzed direct reductive carboxylation of unactivated primary alkyl bromides bearing $\beta$-hydrogens with carbon dioxide under mild reaction conditions. This reaction represents an attractive and operationally simple approach for the synthesis of valuable carboxylic acids from readily available alkyl bromides and carbon dioxide. Furthermore, this unique process for the combination of unactivated primary alkyl bromides with carbon dioxide has considerably expanded the substrate scope for the reductive coupling of alkyl electrophiles. It is therefore envisaged that this new catalytic system and its associated mechanistic insights will provide a platform for the development of novel and more efficient direct carboxylation reactions using alkyl electrophiles and carbon dioxide.

\section{Wenzhen Zhang}

State Key Laboratory of Fine Chemicals, Dalian University of Technology, Dalian 116024, Liaoning, China

Tel: +86-411-84986257

Fax: +86-411-84986256

E-mail: zhangwz@dlut.edu.cn

Received 23 December 2015

Accepted 6 January 2016

Published 5 February 2016

DOI: 10.1016/S1872-2067(15)61037-3

\section{References}

[1] Q. Liu, L. P. Wu, R. Jackstell, M. Beller, Nat. Commun., 2015, 6, 5933.

[2] K. Huang, C. L. Sun, Z. J. Shi, Chem. Soc. Rev., 2011, 40, 2435-2452.

[3] T. Sakakura, J. C. Choi, H. Yasuda, Chem. Rev., 2007, 107, 2365-2387.

[4] C. E. I. Knappke, S. Grupe, D. Gartner, M. Corpet, C. Gosmini, A. Jacobi von Wangelin, Chem. Eur. J., 2014, 20, 6828-6842.

[5] D. J. Weix, Acc. Chem. Res., 2015, 48, 1767-1775.

[6] J. Gu, X. Wang, W. C. Xue, H. G. Gong, Org. Chem. Front., 2015, 2 , 1411-1421.

[7] T. Moragas, A. Correa, R. Martin, Chem. Eur. J., 2014, 20, 8242-8258.

[8] A. Correa, R. Martin, J. Am. Chem. Soc., 2009, 131, 15974-15975.

[9] T. Fujihara, K. Nogi, T. H. Xu, J. Terao, Y. Tsuji, J. Am. Chem. Soc., 2012, 134, 9106-9109.

[10] T. Leon, A. Correa, R. Martin, J. Am. Chem. Soc., 2013, 135, 1221-1224.

[11] A. Correa, T. Leon, R. Martin, J. Am. Chem. Soc., 2014, 136, 1062-1069.

[12] T. Moragas, J. Cornella, R. Martin, J. Am. Chem. Soc., 2014, 136, 17702-17705. 


\title{
Graphical Abstract
}

Chin. J. Catal., 2016, 37: 215-217 doi: 10.1016/S1872-2067(15)61037-3

Ni-catalyzed direct carboxylation of unactivated alkyl electrophiles with carbon dioxide

Wenzhen Zhang*, Chunxiao Guo, Xiaobing Lü

Dalian University of Technology

The Ni-catalyzed direct reductive carboxylation of unactivated primary alkyl bromides bearing $\beta$-hydrogens with carbon dioxide under atmospheric pressure is highlighted. This reaction exhibits excellent functional group compatibility and represents an attractive and operationally-simple method for the synthesis of valuable carboxylic acids from readily available alkyl bromides and carbon dioxide.

[13] Y. Liu, J. Cornella, R. Martin, J. Am. Chem. Soc., 2014, 136, 11212-11215.
[14] X. Q. Wang, Y. Liu, R. Martin, J. Am. Chem. Soc., 2015, 137, 6476-6479.

\section{镍催化非活化烷基亲电试剂与二氧化碳的直接羧化反应}

\author{
张文珍*，郭春晓，吕小兵 \\ 大连理工大学精细化工国家重点实验室, 辽宁大连 116024
}

摘要: 二氧化碳是一种储量丰富且廉价易得的可再生性碳一资源. 化学工作者建立起来的一系列过渡金属催化的 $\mathrm{CO}_{2}$ 作 为羧化试剂的新反应方法学, 成功地将 $\mathrm{CO}_{2}$ 高效转化成在精细有机合成中有着重要用途的羧酸及其衍生物等高附加值的化 学品. $\mathrm{CO}_{2}$ 通常作为亲电试剂或环加成底物与各种亲核试剂或含不饱和键的化合物进行反应. 最近, 过渡金属催化的两种 不同亲电试剂的还原交叉偶联反应作为一种构建碳-碳键的直接而有效的新方法受到了研究者的极大关注. 此种方法不 同于传统的交叉偶联反应, 不再使用难以制备且对水和氧敏感的金属有机化合物, 原料易得且操作非常简便. 其中亲电试 剂与 $\mathrm{CO}_{2}$ 的直接还原羧化反应便是一种合成功能羧酸的更绿色的新方法.

Martin 课题组之前报道了首例钯催化的芳基溴代物与 $\mathrm{CO}_{2}$ 的还原羧化反应. Tsuji 课题组也发现了反应条件更温和的 镍催化的芳基或烯基氯代物与 $\mathrm{CO}_{2}$ 的直接羧化反应. 随后 Martin 课题组发展了芐基氯代物、芳基或芐基酯、烯丙基酯等一 系列亲电试剂直接还原羧化反应. 而对于含有 $\beta$ 氢的非活化烷基亲电试剂, 由于其不易进行氧化加成反应, 同时原位形成 的烷基金属试剂容易进行 $\beta$ 氢消除及二聚等副反应, 使得这类底物参与的直接还原羧化反应极具挑战性.

最近, Martin 课题组在含有 $\beta$ 氢的非活化烷基亲电试剂与 $\mathrm{CO}_{2}$ 的还原羧化反应研究方面取得了突破. 使用锰粉作为还原 剂, 氯化镍乙二醇二甲醚配合物与 2,9-二乙基-1,10-邻菲罗啉配体组成的催化体系能有效抑制 $\beta$ 氢消除及二聚等副反应, 在 室温及常压条件下便可高效地将一系列含有 $\beta$ 氢的非活化烷基溴代物转化成相应的羧酸. 此催化体系的底物适用性很宽, 酯基、氰基、缩醛、醛、酮甚至醇羟基和酚羟基等活泼基团都能被容忍. 他们应用此反应成功实现了具有生物活性的羧 酸小分子化合物的一步合成. 虽然确切的反应机理目前还不够清楚, 但初步的实验表明催化循环中可能包含一价镍物种 参与的单电子转移过程. 基于此反应体系, 他们随后也实现了包含炔基官能团的非活化烷基澳代物与 $\mathrm{CO}_{2}$ 的还原环化/羧 化串联反应, 环状 $\alpha, \beta-$ 不饱和羧酸产品的顺反构型可以很容易地通过底物及配体的选择进行控制.

总之, Martin 课题组发展的镍催化体系在温和条件下实现了含有 $\beta$ 氢的非活化烷基亲电试剂与 $\mathrm{CO}_{2}$ 的还原羧化反应. 此 反应底物适用性宽, 原料易得, 操作简便, 为合成功能团羧酸提供了一种行之有效的方法. 此反应的成功也极大扩展了还 原交叉偶联反应的底物适用范围. 随着机理研究的深入, 更多新型高效的非活化烷基亲电试剂与 $\mathrm{CO}_{2}$ 的还原羧化反应将会 出现.

关键词: 二氧化碳; 镍催化; 还原羧化反应; 非活化烷基亲电试剂; 还原偶联反应

收稿日期: 2015-12-23. 接受日期: 2016-01-06. 出版日期: 2016-02-05.

*通讯联系人. 电话: (0411)84986257; 传真: (0411)84986256; 电子信箱: zhangwz@dlut.edu.cn

基金来源：国家自然科学基金 (21172026); 中央高校基本科研业务费专项资金 (DUT15LAB21); 长江学者和创新团队发展计划 (IRT13008).

本文的英文电子版由Elsevier出版社在ScienceDirect上出版(http://www.sciencedirect.com/science/journal/18722067). 